\title{
The Teaching of Recent and Violent Conflicts as Challenges for History Education
}

\author{
Mario Carretero
}

\section{The Need of an Interdisciplinary Approach to Study Historical Representations}

This is a book about history and therefore about the past. This is also a book about dramatic events that have happened in various societies at different and recent times. In this vein, let us start this chapter with an example of 1838 but being discussed nowadays. "The human cargo was loaded on ships at a bustling wharf in the nation's capital, destined for the plantations of the Deep South. Some slaves pleaded for rosaries

This paper has been written with the support of Projects EDU2015-65088P from the DGICYT (Ministry of Education, Spain) and also the Project PICT2012-1594 from the ANPCYT (Argentina) coordinated by the author. Also this paper has been written during a stay as Visiting Fellow from La Sapienza University (Rome). My gratitude to this institution and to Professor Giovanna Leone for her very valuable comments on this topic.

M. Carretero $(\square)$

Autonoma University of Madrid, Madrid, Spain

e-mail: mario.carretero@mac.com

(C) The Author(s) 2017

C. Psaltis et al. (eds.), History Education and Conflict Transformation, DOI 10.1007/978-3-319-54681-0_14 
as they were rounded up, praying for deliverance. But on this day... no one was spared: not the 2-month-old baby and her mother, not the field hands, not the shoemaker... Their panic and desperation would be mostly forgotten for more than a century. But this was no ordinary slave sale. The enslaved African-Americans had belonged to the nation's most prominent Jesuit priests. And they were sold, along with scores of others, to help secure the future of the premier Catholic institution of higher learning at the time, known today as Georgetown University". ${ }^{2}$

About 180 years later of this incident, the University of Georgetown has decided to offer compensations to the descendants of this episode of 1838. And these compensations are being offered in a context of investigating historically what happened with these 234 slaves and open to public discussion slavery as a general problem of the USA and as a specific problem of the role of US universities in relation to this issue. ${ }^{3}$ Interestingly enough, the National Museum of African American History and Culture has been recently inaugurated being the first important and national museum of this kind. ${ }^{4}$

Definitely this is a very fascinating example of how historical events and representations are not only present as theoretical knowledge in books and archives but on the contrary they are also very alive and can also influence our daily lives as both individuals and societies. The decision of this North American University can only be understood in the context of how slavery has been an important matter on the past of the USA but only recently is being a significant issue in its history (Baptist 2014). As it is well known, the recent past of this country was heavily influenced by slavery as an economic institution, which had an enormous influence on its economic, political, and social and cultural development. Very famous historical events as the Civil War, after the decision of the President Abraham Lincoln of abolishing slavery, and the assassination of Martin Luther King Jr. (1968) because of his activity defending civil rights, cannot be fully understood if we do not take into account that by 1800 about one-third of the population of the South States of USA were slaves from African origin. After the defeat of the South states by the North ones and the abolition of slavery in the whole country, civil rights were not really equal for whites and African-Americans. On the contrary, numerous cases of oppression still existed and this is precisely the main reason for the protests on civil rights leaded by Martin Luther King Jr. by the 1960s.

All this is rather well known and is part of Western popular knowledge due to a number of cultural productions, Hollywood films and TV series 
being very influential ones. But the question, which makes this example meaningful to the matters considered in this book, has to do with how the representation of the past called "history" has being considering this important issue and what kind of implications has this for present individuals and societies.

At this point, we have to establish a classical distinction framed by an also classical question. This is to say, what kind of "history" are we referring to? Elsewhere we have distinguished among at least three kinds of meanings for this label. I mean academic history, also called historiography, school history and popular history. Elsewhere I have considered the main theoretical and empirical differences among these three meanings (Carretero and van Alphen 2017), and it could be considered that the interaction of the three of them make what finally is considered "historical culture" (Carretero et al. 2017), which is not necessarily just only one of them. On the contrary, it could be said that historical culture is the final product of a rich, complex and continuous interaction among the three of them, as it can be seen, for example, in the chapters of this book. In this vein, all of them present specific cases of how representation of the past is both produced and consumed (Wertsch and Rozin 2000 ) by different societies and groups being all of them examples of what academic and professional historians are considering uses of history. In this vein, the chapters in this book of Bentrovato and Bellali in part 1 and Pingel and Zadora in part 2 are very good and specific examples of how that interaction is taking place in different national and regional present contexts.

In this occasion, our reference to this issue will be briefer and we will introduce these differences by the comparison among the way these three "histories" have considered the slavery in the USA, as an example of how historical knowledge can be much more surprising than we probably think about it. Let us start by historiographical knowledge. In this case, it is fascinating to see how the topic is receiving an increasing interest by North American historians, which means that it was not considered for a number of years. Of course one wonders how this could happen taking into account its importance and enormous influence. In general terms, it could be said that probably slavery was not important because slaves were not the main actors of the US historiographical narrative which like many others is a national one, and it is devoted to the master narrative of the nation (vanSledright 2008). Definitely this has been changing in the last years. 
Let us move to school history. In this case, research by Epstein (2009) has clearly indicated how high school North American students having an African-American origin overtly reject numerous school contents about the past of their nation. This is due mainly because they consider these contents as not representative of their past. Consequently, there is a process of cultural and educational resistance in relation to hegemonic historical school contents, which include textbooks and teachers lessons. As a matter of fact, US history textbooks have received numerous criticisms because of their contents, which traditionally were not inclined to include minorities in their contents. It is important to notice that in this case the so-called minority is bigger than the population of many European Union states. Interestingly enough, these processes of resistance studied by Epstein (2009) and other authors are also showing that not only African-American but also the rest of students are not being taught essential parts of the construction processes of their nation.

And finally if we consider popular history in general terms, it can be said that films and TV series are, for example, Kunta Kinte, based on the novel Roots: The Saga of an American Family (Haley 1976), Forrest Gump (1994) and a number of similar and related cultural productions have very much influenced the view we all have about slavery and other recent events in the USA and, as a consequence, in other parts of the planet. Thus, many of these films have been able to show not only the cruel details of slavery but also its importance as a social and economic institution and the way it determined the life of millions of people for generations. In sum, the access to the representation of the past of those important topics comes from an interaction of the three types of historical knowledge and not only from one of them, as stated above. Also any of these types of historical knowledge is definitely influenced by the other two. Therefore, academic history is not the only one, which establishes reliable and valid representations of the past. Historiography is also a social practice and as such could be influenced by specific views about what will be studied and how. For example, it could "forget" to study slavery for a number of years, as it is being considered in this case. Thus, in the last decade research has been able to show that most of historiographical productions since nineteenth century has been basically influenced by the idea of nation (Berger 2014). In other words, the main subject of academic historical narratives has been the nations as such, and this has implied both an exclusion of heterogeneity and the construction 
of imagined homogenous national people (Anderson 1983/1991). Obviously slaves, natives and women were not included in that idealized and essentialist canon. And this is probably one of the reasons the present decision of Georgetown University is surprising us even nowadays.

Meanwhile, school history was created as a compulsory subject matter by all nineteenth-century school systems precisely to indoctrinate students with their national histories. There is more than anecdotal evidence that school history and historiography as an academic profession were born mostly at the same times everywhere (Berger 2014). Thus, it can be said that to a great extent school history was born as the little sister of national historiographies. But it is important to take into account that unfortunately the school history has not experienced the same transformation as national historiographies did particularly since the second half of twentieth century when the Annales School (Burke 1990), the History of Mentalities (Braudel 1990), the History of Private Life (Aries and Duby 1992), The History of Gender (Rose 2010), the Global History (Conrad 2016) and other trends introduced enormous changes in this field. On the contrary, school history has suffered a number of changes, which will be presented below but still in many societies historical contents play a role, which is closer to the local nationalistic goals and their associated tensions than to present renovated historiographical approaches (Foster 2012).

It is important to consider that popular history (Groot 2016)-from historical novels, museum exhibitions, heritage sites, to films, television shows and documentaries, Web sites and apps-has experienced an enormous expansion since the fifties due to the enormous development of media and particularly the digital revolution. In this respect, the words of a very prestigious historian as Le Goff should be considered: "Memory (as popular history) is a conquest, it must seek and preserve that what allows it to construct itself from a perspective of truth. It must dispel false legends, black or golden, about such episodes of the past, collect the maximum amount of documents and confront contradictory memories, open up the archives and impede their destruction, know to look for the memory expelled to the taboos of history during certain periods in certain systems in literature or in art, and recognize the plurality of legitimate memories" (Le Goff 1990, p. 15). It is important to take into account that Le Goff wrote this paragraph in a presentation of a book about how the collapse of communist countries after the fall of 
Berlin's wall triggered an intense process of recovery of collective memories about essential portions of the past silenced by soviet historiography, which severely censored historiographical research. As Hein and Selden (2000) showed, these attempts to censor history were also successful at least in relation to a number of events in democratic countries as Japan, West Germany and the USA.

In this vein, it is important to mention that for centuries human beings consumed historical representations basically through heritage related to monuments, traditions and museums. In general terms, most of this knowledge was considered in a fixed and dogmatic manner (Lowenthal 2015). But nowadays popular history is playing an important role having an influential interaction with both academic history and school history. As Kansteiner (2017) has noted, historians did not pay attention to historical films until rather recently because these were not considered reliable views on the past. But as mentioned before films and other products of popular history have been very influential in our views on various topics as slavery and its influence on the development of societies.

In conclusion, the study of how different representations of the past are both produced and consumed by individuals and societies needs to be studied from an interdisciplinary point of view (Carretero et al. 2017). It is striking that the research agendas of the historical discipline, the philosophy of history, history education and popular historical culture are still so separate. So far the boundaries have been blurred only in rare instances (Berger et al. 2012; see also Retz 2015 for an analysis of the interface of academic history, school history and the philosophy of history), although these fields can learn a lot from each other. Without this kind of approach, it is almost impossible to understand how a social and cultural phenomenon as the so-called history wars (Grever and Stuurman 2007; Taylor and Guyver 2012) is taking place since the beginning of the 1990s when globalization started its increasing trend. Most of the chapters of this book have to do with different cases of these wars and should be understood in that context where just one discipline is not enough to make sense of its profound meaning.

In this vein, this chapter deals with these objectives. Firstly, a view on the contributions and advances of history education in the last decades will be presented. This will allow us to examine the context of possible educational changes to be implemented in the cases presented in the chapters of this book. The specificity of teaching violent and recent 
events, related to political conflicts which are still running in many cases, will be taken into account. As it can be easily imagined, it is not the same to teach, for example, the history of Roman Empire than to discuss in the classrooms about a national civil war that happened one or two decades ago. In this respect, most of the present advances on history learning and teaching research have to do with how to teach and learn historical contents (Seixas 2017). On its part, most of the research on history textbooks has to do with what is included in the textbook. In other words, the first kind of research has to with the consumption by citizens of historical contents and the second one with the cultural production of them. As it is well known, these two cultural processes do not follow always parallel tracks. This is to say, what is in the minds of the students is not necessarily in the textbooks and vice versa. In this chapter, I will argue that in the area of research of history education, and particularly in the field of the role of history education for conflict resolution and reconciliation, we need to establish a more meaningful relation between these two areas of research if we pretend to implement possible, effective and meaningful improvements in the future. Also, the issue of for what purposes should history be told will be considered because it affects also the objectives of this book.

\section{History Education as an Evolving Field}

Regarding the production of representations about the past, different researchers have considered the existence of competing objectives of history education (Barton and Levstik 2004; Wineburg 2001). Carretero (2011) has redefined these objectives as "romantic" and "enlightened," because their features and functions stem from their intellectual roots in romanticism and the enlightenment, respectively. In that sense, history has been taught in all national school systems so as to make students "love their country" (Nussbaum and Cohen 2002) and to make them "understand their past" (Seixas 2004). In a romantic vein, history education is a fundamental strategy used to achieve: (a) a positive assessment of the past, present and future of one's own social group, both local and national, and (b) an identification with the country's political history. In an enlightened vein, history education aims at fostering critical citizens' capability of informed and effective participation in the historical changes happening nationally and globally. This can involve a critical attitude toward their own local or national community, or even larger political 
units. Recently, this has been translated in several countries into the following disciplinary and cognitive objectives: (a) to understand the past in a complex manner, which usually implies mastering the discipline's conceptual categories (Carretero and Lee 2014); (b) to distinguish different historical periods, through the appropriate adequate comprehension of historical time (Barton 2008); (c) to understand historical multicausality and to relate the past with the present and the future (Barton 2017); and (d) to approach the methodology used by historians, such as comparing sources (Wineburg et al. 2010).

The main and almost exclusive objective of history education in many countries has been since the end of nineteenth century the national indoctrination of students via the transmission of an invented national past. History education received much critique during the decades between WWI and WWII, because it became clear that its contents and approaches were saturated with blind nationalism and a very stereotypical view of other nations, nationals and their pasts, particularly of neighboring countries. For example, Boyd (1997) has analyzed the pioneer contribution to this respect of Altamira (1891), a Spanish intellectual who contributed meaningfully to the League of Nations and who was the author of one of the first books on history education. As a matter of fact, it was even suggested to eliminate it from the school system. The enormous human and political catastrophe of WWII demonstrated that blind nationalism was a real and unfortunate fact. Since the 1970s and 1980s, history education's interest in providing students with a critical view of social and political issues of different societies in the past has increased. One of the important factors contributing to this improvement has been the gradual inclusion of social sciences contents in history curricula, as some important educational thinkers were able to foresee (Dewey 1915; Piaget 1933). This feature has implied that school historical contents have tried to incorporate questions and explanations related to how societies change across times and not to include just single and closed narratives about the past of the nations.

In this vein, the field of history education suffered an important change in the early 1980s when Dickinson et al. (1984), (Shemilt 1980) published a number of books and papers that introduced innovative ideas on this theoretical and applied area of research. Up to this point, the teaching of history faced two main problems. On the one hand, a number of researchers indicated a very low performance on school historical knowledge (Ravitch 1987), probably due to a lack of interest in learning 
about it, which was not significant enough for the students. On the other hand, history as a school subject was characterized by rote memory and copy and paste practices. Enormous list of dates, battles and main characters were the typical contents of school history in most of educational systems. For example, most high school history textbooks in the USA never had less than 500 pages, but at the same time research in text understanding was clearly showing that students had a very poor comprehension of basic history contents constituted by canonical historical narratives such as the one on the Boston Tea Party (Beck and McKeown 1994; Barton and Levstick 1996). ${ }^{5}$

Unfortunately, even nowadays this continues to be the usual picture. Reacting to this situation and with a much more active and constructive view on learning in mind, a number of educational proposals started to be developed in the 1980s. For example, in the UK the 13-16 History Curriculum was developed and applied in a great number of schools (Shemilt 1980). These developments were based on the importance of academic discipline for educational practice. This is to say, the goal of education rather than transmitting a considerable amount of consolidated academic knowledge was to initiate students in the practice of historiographical procedures through an emphasis on their own cognitive activity. In this respect, Collingwood (1946) was an influential author, as in Idea of History he developed his metaphor of the historian as a detective. Thus, the 13-16 History Curriculum proposed that students had to find out, for example, how and why a specific and decisive historical event had happened instead of just memorizing an enormous list of names, places and specific dates, including also specific predetermined glorious narratives. Also, from this new educational perspective, students had to contemplate the role played by some main characters. For this purpose, students had to examine and critically discuss a number of data and historical texts about that event in order to test their hypothesis. In this vein, the general idea was to base history education on thinking abilities and active knowledge and not only on just an accumulative process of storing information.

At that time, the work by two celebrated psychologists, Piaget (1966) and Bruner (1966), also resonated in the field. Both authors defend a constructivist view on learning and share the idea of knowledge developing in the student's own cognitive activity. They were considerably successful defending the idea of the students' discoveries as a sign of autonomous and active cognition. Furthermore, Bruner's idea of 
establishing meaningful relations between school contents and academic disciplinary developments was quite influential. ${ }^{6}$ In this vein, one of the main advances developed by Dickinson et al. (1984) was the difference between first- and second-order concepts in history. First-order concepts were related to specific historical concepts such as "monarchy" and "feudalism." Second-order concepts were related to students' ideas about how historical knowledge is constructed. These involve time, historical causality, significance and evidence. In other words, the idea of history education as a pedagogical endeavor centered not only on specific data but above all on developing disciplinary thinking and reasoning. Accordingly, history classes should be considered an opportunity for thinking historically and not just for accumulating historical information by rote memory (Carretero and Voss 1994). About 20 years later, these initiatives were a basic support for fully developed educational programs, such as the one designed by Seixas (2004; Seixas and Morton 2013) in Canada around the idea of historical consciousness, also influenced by German authors such as Rüsen (see Retz 2015, and Seixas 2015, 2016, for reviews on these specific developments). This program has been developing six essential historical "second-order concepts" (causality, etc.) as the center of its educational efforts. According to this initiative, students should accomplish a full understanding of these concepts to achieve a disciplinary view of historical contents.

Some years after the first mentioned British publications, Wineburg (1991) published a seminal empirical paper about historical problemsolving. His work in the USA was influenced by cognitive theories (Chi et al. 1988) relying on the comparison between experts (historians in this case) and novices as an essential research strategy (Limón and Carretero 1998). Wineburg was also convinced of the importance of teaching historiographical methods instead of emphasizing rote memory of historical contents. His support of the importance of developing student's inquiry activity was also clear. More specifically, his study (1991) analyzed the differences between one group of historians - history experts - and a group of high school students in their senior year when faced to solve a historical problem. This task was basically related to the most important events of the Lexington Battle (1776) in the context of the American Revolution. Participants were provided with pictures and documents of that period and had to interpret them as possible historical sources. The fundamental differences found between the two groups were related to the experts using heuristics to base their inquiry. Thus, one conclusion 
of this work was that the use of three heuristics would significantly improve evidence evaluation on the part of the high school students. The first heuristic was defined as corroboration or the act of comparing documents with one another. The second one, sourcing, was defined as the act of looking first to the source of the document before reading the body of the text. The last heuristic is contextualization considered as the act of situating a document in a concrete temporal and spatial context. These and related ideas produced the development of educational programs like Reading like a historian (Wineburg et al. 2011), which has had an enormous impact on schools in the USA and other countries. ${ }^{7}$ The approach developed by Wineburg and colleagues (Nokes 2017; Wineburg et al. 2010) emphasized both reading and writing as essential cognitive abilities related to the specificity of history as a discipline and tend to use the term historical thinking as the initiatives leaded by Seixas also do (see http://historicalthinking.ca/ and also https://sheg. stanford.edu/). In both cases, the emphasis has been on the cognitive activity of student as a learner of historical knowledge. This underlying idea can be also found on related efforts as the work of vanSledright (2010). But there are also interesting efforts which emphasized the idea of the student as a social learner from an interactionist point of view.

In a European context, van Boxtel and van Drie (2017) have developed a fruitful instructional initiative through a dialogical framework. They consider learning as entering into a community of practice (Lave and Wenger 1991) and achieving specific concepts and procedures. From this point of view, the historians' practice is also based on a dialogical activity. The work by van Boxtel and van Drie stems from the abovementioned contributions about fostering historical thinking and also emphasizes the use of documents and evidence. However, based on Bakhtin's ideas (1981) about the nature and importance of dialogue, they think that historical expertise is not only based on individual cognitive operations, such as the sourcing, corroboration and documentation related to historical text inquiry. For them, it is also essential to consider dialogical activity, mostly in relation to multiple views on both historical narratives and concepts. Therefore, they confront students in the classrooms with a number of dialogical activities in which they have to compare and evaluate different views on the same historical issue. More specifically, these activities have to do with asking historical questions, connecting events, developments and actions through a historical 
contextualization, using substantive historical concepts (facts, concepts and chronology) and also historical meta-concepts and supporting claims with arguments and evidence based on evaluated sources. All this always in a context of the importance of dialogue in classrooms activities. The authors maintain that these components are powerful enough both to trigger historical interest in the students and to improve epistemological beliefs Maggioni et al. (2009) about history as a subject matter. They thus help students to understand that disciplinary historical problems have no closed answers already established in a definitive narrative but, on the contrary, that these problems can be investigated and interrogated as ways of inquiring about past societies and looking for different interpretations. Therefore, these efforts try to develop critical thinking and intellectual autonomy among the students using not only reading and writing activities about historical sources in the classrooms, but also an intensive dialogue about them and the conceptual problems they are associated with. These ideas are in line with some recent research (Freedman 2015) that insists on providing more opportunities for students to develop critical thinking through the introduction of a broader variety of sources and to insert their historical evidence in the context of general interpretations or "frames."

\section{How to Improve the Teaching of Recent, Conflicting And Violent Past?}

Once we have described the main developments of history education, we will elaborate how these and related contributions could improve it in the contexts related to the papers of this book. As it was mentioned above most of the educational developments in this field have to do with how to teach historical contents in order to achieve a meaningful and disciplinary understanding. But most of the chapters of this book have to do with what is present or absent in the narratives included in the textbooks, what has been eliminated and what kind of version is being offered to the students and teachers as present and future citizens about recent conflicts. As it was announced above in this part of this chapter, I will argue that a meaningful relation between these two important aspects of history education should be elaborated in order to improve history education in conflicting contexts.

If we examine the historical topics and issues considered by most of the chapters, two features clearly appear. On the one hand, most of the 
historical events have a national character and not a regional or worldwide one. This is to say, these events only make sense in the context of specific national histories. There are only two exceptions in the whole book. In one case (Psaltis, Franc, Smeekes, Ioannou, Žeželj, Chap. 4), similar processes are compared in three different countries. The other case is the study about the teaching of the Holocaust (Bilewicz, Witkowska, Stubig, Beneta and Imhoff, Chap. 6), which is obviously a historical issue affecting several countries. But in this case it is considered mainly in relation to a specific national case, the Polish one. On the other hand, all the papers deal with recent events. This is to say, they are devoted to analyze recent issues, which have happened less between 50 and 100 years ago, or even less. In other words, what most of these papers do not consider is a big historical event, for example WWI or WWII, the colonization of America or the industrial revolution, which are classical and common topics in most Western history curricula.

Thus, these two features of being recent and national are the main origins of the difficulties for teaching conflicting historical issues. The reasons are almost obvious, but it is important to mention them. Precisely because those events happened so recently, there is a direct continuity between past and present historical subjects, as it was easy to see in the example of the slavery of the USA mentioned at the beginning of this chapter. These type of cases are very numerous. They can be found everywhere, and they show how historical knowledge not only is very alive but even it can be said that "history can bite" (Bentrovato et al. 2016). Interestingly enough, these cases appear even in contexts where apparently there is no conflict. For example, in the case of Spain (Valls 2007) most of the direct descendants of the victims assassinated by the Franquist (circa 160,000) during the Spanish Civil War (1936-9) are still asking for government support to recuperate the corpses. ${ }^{8}$ Neither those victims nor their families have ever received any kind of recognition by the Spanish government. In other words, recent historical conflicts very often trigger emotional judgments and representations, which could last several generations. Therefore, these views tend to be very durable, and they also are very difficult to change as numerous social psychology works have been able to show.

Also, recent conflicting historical events are a very important source of national identities. These identities are also based on remote historical events, which have considered as nations myths of origin by classic historical research (Hobsbawm 1990). But definitely events that have 
happened less than 50-100 years have a tremendous influence on citizens view on the past because it is considered by citizens also part of the present (Shemilt 2011). As a matter of fact, they are not part of the present, but to some extent it is understandable that people could think of it in that way because definitely these events have consequences in the present. In other words, it is really complicated to establish and to maintain a historical distance which could favor an objective analysis because there are still many present influences like the ones from media and family which in general do not favor the process of beliefs change, revision and possible reconciliation. On the contrary, in general terms these influences tend to maintain consolidated views on recent conflicts because they are part of their belief systems.

In my opinion, there is a key central idea on present developments of history education. This idea was labeled by David Lowenthal (1985/2015) about 30 years ago by the title of his very influential book The past is a foreign country, and it was even continued by another very important contribution in our field. I mean the book by Sam Wineburg (1991) Historical thinking and other unnatural acts. These two contributions have developed the very essential idea that a clear separation is needed between the past, as part of our cognitive, emotional and social phenomenological experience, and the historical attempts to analyze that past through systematic and analytical ways and disciplinary methods. In my opinion, we need to develop more profoundly these ideas because they have a central importance for both remote and recent historical events.

In other words, history seems to be about everyday, common-sense things. So many people believe that history can be understood simply by applying common-sense understandings. Thus, when historical concepts appear like "king," "bourgeois" or "colonist," people think they refer to their present experience of those concepts but in fact they refer to very different representations. Of course the same could happen with concepts related to relations and institutions and not only to individuals, like "feudalism" and "republican state." This misunderstanding is in the base of most erroneous representations of the past, and it is central to history education. Therefore, in this chapter, I argue that this simplistic view of history learning is a mistake. Four decades of research suggest that thinking historically is counterintuitive (Carretero et al. 2013; Carretero and Lee 2014; Lee 2005), as it is also the learning of scientific concepts. Three decades of research on different subject matters (Vosniadou 2013) 
have shown us that meaningful learning implies important processes of radical conceptual change going from the intuitive notions to more complex ones. In this vein, history requires understanding concepts that differ from everyday conceptions and explanations. Some everyday ideas are completely incompatible with history; many students, for example, believe that we can only really know anything by directly experiencing it (Cercadillo et al. 2017) and vice versa. This is to say, some students think that whatever is experienced directly through viewing a film or a historical image, for example, corresponds necessarily to true knowledge without taking into account that the film and the image are also cultural products which should be analyzed according to theoretical concepts and theories.

Thus, in order to improve students understanding of history as a representation of the past which is unnatural and counterintuitive, it would be important also to contribute to their decentration through the presentation of alternative views. No doubt multiperspectivity could play an essential role in this process. As a matter of fact in the field of social and civic education, the presence of controversial topics in the classrooms has been proved as a very effective and productive way of changing students minds and improving their reflexivity on these issues (Hess 2004). But multiperspectivity has to do basically with what students should learn and not necessarily with how to learn it.

In this respect, present developments in history education, as the ones described above, related to historical thinking and historical consciousness could contribute very much to a better learning and teaching methods of recent and conflicting historical events. This is to say, alternative views could be presented emphasizing underlying issues of historical significance, change, causality and time (Seixas and Morton 2013). Let us briefly unpack these important questions.

- Significance. The past is full of events. If most of the history curricula in Western countries are related to some set of common topics is because there is a selection of these events based on particular views on our culture. In other words, these views attribute significance to some events compared to others because Western nations share some common views on the past. For example, these views could be related to the colonial experiences (since fifteenth century to nowadays), and they could also generate different and even opposite views on certain phenomena. It is really important for the 
students to elaborate and to discuss why and how historical events are selected to form specific narratives about certain periods of the past and also make explicit the underlying cultural belief systems that support those attributed significances.

- Change. History implies necessarily to study how human societies have changed through time and space. This is related to the need of establishing connections and similarities among different human groups and societies in diverse moments and milieus of the planet. It also implies to distinguish between short- and long-term changes. Therefore, it is also related to differentiate change and continuity, as it is applied in different historical periods. Very often these processes of change are violent and traumatic, but their importance usually goes beyond the recognition of those dimensions because historical changes also have durable consequences affecting distinct aspects of human societies related to economy, culture, politics and economy.

- Causality. That is, the need to see the causality of historical events in a complex way, determined by multiple causes. On the one hand, students very often tend to maintain just a historical perspective based on just one single cause. But social and historical problems are complex because they imply an interaction of different types of causes. Most of dramatic and important historical events are very dependent on contingencies, and the nature of it implies a sophisticated causal representation. On the other hand, it is very important for students to distinguish between immediate and remote causes because they are inclined to see the more recent causes as the only ones or at least as the most influential. The interaction of these two types of causes is also an essential component of historical consciousness that students should achieve.

- Time. As it is well known, there is not history without time. This issue will be discussed below, in relation to the understanding of historical narratives. In this vein, historical time is an essential component of the distinction between myths and historical explanations. To understand historical time (in terms of centuries, Christian, Jewish and Islamic chronologies, for example) it is necessary to first comprehend physical time (in terms of hours, days and seasons, etc.). But the comprehension of physical time is not sufficient to understand historical time because this is also associated with cultural and philosophical views on the relation between time and events (Lorenz 2017). All these issues imply important 
conceptual issues that should be developed by an innovative and active view of history education.

\section{National Master Narratives and Concepts as an Obstacle for History Education}

One of the objectives of this book is related to the problem of how to improve history education in order to overcome political conflicts and to promote reconciliation applying the contributions of social psychology. One important source of information for this purpose comes precisely from social psychological studies that inform us about the features of citizens' intuitive representations of the past. These features are important because they would indicate what should be changed if a complex and historical disciplinary conception of the past is pretended. Thus summarizing a number of studies comparing quantitative studies carried out in numerous countries (Paez et al. 2017), it can be concluded that,

- Lay historical representations tend to be rather concrete and are based on specific, anecdotal and personalistic episodes. Abstract principles and processes are difficult to understand.

- In this vein, wars and national heroes as well as social and political leaders are seen as having had an enormous influence as initiators of historical change.

- Causality tends to be seen in a simple rather than complex way. In other words, historical issues are considered to depend on just one single cause instead of considering them in a multicausal way.

- Recent historical events (i.e., occurring in the last 100-150 years) tend to be seen as much more important than remote ones.

- Historical events and problems are predominantly viewed as situated in the West. That is, historical developments are seen from a colonial perspective. Post-colonial views are not that common even in countries with recent post-colonial experiences. This implies that an international perspective on a historical matter is harder to grasp than a local or national perspective.

These results from social psychology studies have clear educational implications for the teaching and learning process of recent and violent historical conflicts. 
But it is also important to realize that historical recent and conflicting events, as the ones mentioned in the chapters of this book, are basically national as mentioned before. For this reason, I will discuss present research about how national narratives are understood by students and how this has a clear implication for the understanding of the concept of nation. It is important to notice that historical narratives and concepts are theoretical-related constructs, and both have serious implication for possible educational developments in this area. In this vein, I argue that the complex relation of concepts and narratives is essential to fully understand how history is represented (Carretero et al. 2013). For example in any specific narrative not only is important who is the main actor of the narrative but what kind actor is. This is to say, the actor could be a personalistic and concrete one as a particular political leader or the subject could be an abstract and more complex one as a historical concept like the bourgeoisie. The difference is really important because in the first case the causal structure of the historical event explained by the narrative could be reduced to the particular attempt of a specific person. In the second case, the student needs to apply a more abstract and complex scheme. A clear example of this difference can be seen in the distinction between understanding the Holocaust as a terrible set of events caused by a specific group of people, Hitler and the Nazis, and a more sophisticated representation which situates this terrible issue in the context of various and complex historical agents.

In my work about how the representation of national narratives and concepts (Carretero 2017; Carretero and van Alphen 2014 ; Lopez et al. 2015a, b), six dimensions have been considered. This is to say, (a) who is the narrative's historical actor, (b) an identification process with that actor, (c) a very simple and concrete causal story based on the fight for freedom or territory, (d) the historical narrative itself as a moral vector, (e) the presence of heroes as non-historical figures and (f) an essentialist view of concept of nation.

I will present them summarizing the main empirical findings and developing those implications. But firstly it is important to remember that from a sociocultural point of view (Wertsch 2002) there is a fascinating coincidence between school historical master narratives and the myths of origin which provide ideological support of any nation (Anderson 1983; Hobwsbawm 1990). As Wertsch and Rozin (2000, p. 41-2) recognized, 
three basic functions of an official history $[\ldots]$ first $[\ldots]$ a kind of cognitive function having to do with cultural and psychological tools required to create what Anderson (1983) has termed "imagined communities", especially nation- states $[\ldots]$ without instruments such as print media, maps, and texts about history, it may be impossible to imagine communities or to "think" the nation $[\ldots]$ a second function of official histories is to provide citizens of nation-states with some sense of group identity [...] the third related function of official histories is to create loyalty on the part of citizens to the nation state.

In this case, both authors, Anderson and Wertsch, are referring mostly to rather remote master narratives and not to recent ones. The so-called official history, which has coined that way by the pioneer of this field the French historian M. Ferro (1984/2004), is opposed to the "un-official" one which is expressed by the representations of minorities groups which do not have the support of the nation-state. But in my opinion these concepts could perfectly be applied to narratives related to more recent events as the ones mentioned in the chapters of this book. It is important to realize that all the official master narratives started at some point of history as cultural artifacts designed to contribute to the invention of the nations and the national communities. Of course the remote ones, for example the narratives of the independence of American countries as a saga of "the people" fighting against the oppression and looking for freedom (van Alphen and Carretero 2015), have a longer tradition than the more recent ones but the latter are closer in time, and this provides stronger ties for the reasons mentioned above.

The first dimension of master narratives analyzed in our studies is the establishment of the historical subject. That is, the establishment of the nation and its nationals as preexisting and everlasting historical subjects. This dimension is crucial because it determines the main protagonist or voice of the narrative. As it is well known, any narrative strongly depends on who its subject is. This historical subject is established in terms of inclusion and exclusion, radically opposing it to other as a coherent and homogenous group. Our results indicate that after years of history instruction both Spanish and Argentinean high school and university students tend to consider the national "people" as a clear a definite historical subject, which already existed even before the political birth of their nations by the beginning of nineteenth century. For example in the case of Spain (Lopez et al. 2015a), our participants think that the 
Spanish people were fighting against the moors for several centuries, but it is not the case at all because at that time in the territory of the Iberian Peninsula there were several kingdoms as Castille, Aragon and others. Spain did not exist until several centuries later. In the case our work in Argentina (Carretero and van Alphen 2014), high school students considered that the Argentinean people fought against the Spanish to achieve their independence and they thought of that people as a homogenous entity very similar to what is today the citizenship. But it was not the case. The so-called people who developed the independence of most of American colonies were just a small proportion of the population, which did not include natives, slaves and women. Obviously the concept of citizen at the beginning of nineteenth century has not the same meaning as it has today. As a consequence of this, it can be concluded that there is a trend in human beings to establish a historical continuity in relation to present and past political subjects even though it does not exist at all.

This idea of continuity has been found also by numerous social psychology works (Smeekes 2014). For example in this book, the work of Psaltis et al. (Chap. 4) is a clear example of this. Therefore, there is a clear coincidence between the research from history education and social psychology studies, which constitutes a firm base to suggest a number of educational implications. Probably the most important one is to help the student to deconstruct the mentioned historical subject. In other words, to contribute to a clear representation of the difference between past and present political subjects. Of course this is also related to the improvement in the comprehension of past and present historical subjects as heterogeneous entities instead of homogenous, essentialist and idealized ones. It is also important to take into account that in the case of recent events the notion of continuity is very controversial and difficult to challenge. As a matter of fact around this notion, we find a real conundrum in both epistemological and educational terms. This is to say, if the historical event is a remote one the continuity between the past national subject and the present one is arbitrary and also invented (Anderson 1983). In other words, the Spanish, the Italian or the Jews citizens of fourteenth century, for example, have no real continuity with the present ones because of many reasons (Sand 2010). The most important reason is the process of demographic interaction between different populations due to migrations, wars and other social and political events over the centuries. Also, this is because the very concept of a national group did not exist until the nineteenth century. But when the historical 
event is a recent one, the continuity does exist. For example, in terms of the example presented in the beginning of this chapter, the slaves sold by Georgetown University by 1834 have descendants and they are of course the continuation of their antecedents. Also they could ask for compensations in terms of real or symbolic actions. Therefore, there is no doubt that in the case of recent events, as stated above, to promote a historical distance implying the deconstruction of the historical subject of the narrative is a very complex matter. In my opinion, this conundrum only has a possible way of solution. I mean to look to the future. This is to say to look for a better future based on reconciliation, and at this point social psychological theories have a significant contribution to offer as it has been stated in Introduction.

The second dimension studied is the presence of an identification process with the mentioned historical subject and its political unit. This dimension is related to the previous one but is focused on a distinctive aspect. For example in one of our studies (Lopez et al. 2015a), students were asked about the presence of the Arabs in the Iberian Peninsula for about 800 years. In many cases, these students used the pronoun "us" in their narrative even though they were referring to events, which happen several centuries ago. Clearly they did as a sign of this identification process, which obviously has also emotional components.

In this case, the educational implications are also very straightforward. It has to do with the development of a teaching strategy devoted to be conscious of this identification process. Probably if this consciousness takes place, it could contribute to a more flexible view on the cultural and national identity of the students and this could help to acquire a more disciplinary view on historical matters.

The third dimension is related to the existence of a "natural" territory belonging "since ever" to the nation, instead of conceiving the correspondence of nations and their territories to be the result of different political, social and historical complex processes along several decades or even centuries. This dimension probably varies among different groups of students coming from different nations because not all the nations have historically developed the same relation with the issue of territories. In our studies, it looks like that both students of Spain and Argentina consider their present territories in an essentialist way instead of in a historicist way, as mentioned above. In one case, students thought that the Spanish territory existed since at least the Roman Empire times. In the case of Argentina, our students defended the idea of an Argentinean 
territory, which was basically the same than the present one and which existed since the Spanish colonization. Therefore, in both cases the essentialist view on the territory is basically very similar.

In this vein, this is precisely the conceptual and representational change that education should be able to produce. In other words, to move the students from a more intuitive and superficial notion of the territory to a more sophisticated notion. This involves a consideration of how territories have changed at different historical moments and that borders do not last forever. On the contrary, they express different political processes and conventions: in some cases peaceful and democratic ones but in other cases violent and dictatorial ones. In relation to the territorial dimension of the concept of nation, we would like to emphasize the need and the convenience of introducing historical maps to the school teaching activities. Historical maps are an essential part of historiographical literacy and research, because they provide a clear and precise representation of how territories and nations have changed along centuries. But unfortunately, many students tend to consider the present maps as either immutable or they are cognitive anchors for representing historical events and political changes. In relation to this, recent historiographical research has showed that the so-called historical rights are based on rather invented knowledge about historical limits (Herzog 2017). This is to say, many of the ancient historical limits never existed as very precise borders. Therefore, it would be unjustified to use them to maintain territorial rights based on supposed past evidences.

The fourth dimension I have studied in my research has been the presence of mythical and heroic characters in student historical narratives (Carretero and Bermudez 2012). I think this is particularly important for the type of issues related to the chapters of this book. Most of historically recent and violent events include a number of heroic characters. This is to say specific persons who have played an extraordinary role on the main events of those master narratives, as it is the case of national heroes. In this vein, there are a number of fascinating and intriguing issues to be discussed having most of them clear educational implications. Firstly, specific research about students lay views on historical causality shows that they tend to attribute more influence to specific individual characters than to social and political structures (Carretero et al. 1997; Halden 2000). But this importance is much broader in the case of heroes. To some extent, it could be said that students and citizens in general recover the classical Greek meaning of heroes and myths to 
apply it to master narratives and their protagonists. Let us remember that one of the main differences between historical and mythical explanations is precisely the absence of specific time and space constraints in the latter. It is totally irrelevant, for example, to know Oedipus' date of birth or any other specific temporal and spatial markers. Myths and mythical figures are basically universal and not local narratives. In contrast, one can say that history is making its appearance when time and its specific cultural and spatial constraints are introduced into a narrative. The appeal of mythical national narratives probably builds on how important are myths for present human societies as historical and philosophical research has noted (Gadamer 1999; Lorenz 2014). Also, the classical Greek meaning of hero consists of being something intermediate between the Gods and the human beings and accordingly to be able to perform extraordinary things. These actions are usually in favor of a specific group, national or cultural, of human beings, and they imply a total loyalty and devotion to the hero, which of course become a model for that group. Interestingly enough, it is very common in the field of history education to see how the heroes of specific national groups are either silenced or strongly criticized by the opposite national groups. In other words from a social psychology point of view, the heroes of the in-group is at the same time the antihero of the out-group. For example in our comparative study of Mexican and Spanish history textbooks, Columbus appears in Mexican books either silenced or having no historical merits at all but in Spanish ones is a hero having very important merits from a scientific, cultural and historical point of view (Carretero et al. 2002).

The educational implications of these issues are basically related to the need to favor a historiographical understanding of these main specific characters. This is to say to develop among the students a complex comprehension of the so-called heroes. Probably the first thing to take into account is to develop a reflection on the process of historical invention and selection of national heroes because an important number of them are part of cultural artifacts developed by political elites in order to build national communities. Secondly, it would be important to transmit to the students that most of the extraordinary actions performed by historical characters only can be fully understood in the context of a number of specific historical conditions. In other words, I think it is educationally worthwhile to make the students progress from the universal "programmatic mythology" of nations (Hobsbawm 1990) to the local specificity of historical explanations including their social, political and 
economic complexity. Also well-established theories of narrative development (Egan 1997) claim that human beings develop a narrative ability which goes through a number of stages: somatic ( $0-2$ years of age), mythical (3-6), heroic (7-10), philosophical (11-15) and ironic (15 and onwards). Thus, if national historical narratives often maintain their mythical and heroic components even during adolescence and adulthood, time at which individuals should be able to generate philosophical and ironic historical narratives, it is work investigating what kind of social psychological mechanisms yield a contrary result.

The fifth dimension of the narratives I have explored in my research is the application of moral features, which legitimize the actions of the nation and the nationals. This is to say students tend to view national master narratives as moral vectors maintained by the values of nation. For example, Carretero et al. (2012) have found that Spanish young adolescents considered that Christians have the right to "recuperate" the territory of the Iberian peninsula, inhabited by the Arabs for 800 years, because it was considered "Spanish territory," as it is nowadays. On the contrary, according to the same students, the Christians have no right to conquer the American territories because they belonged to the natives. Therefore, the master narrative establishes the distinction between "good" and "bad" options, people, and decisions. Typically, the first one is associated with the national "we," and the second one is related to "they." Thus, the logical and moral truth is always on the "we" side. Secondly, master narratives offer living examples of civic virtue, particularly of loyalty. As it can be easily inferred, this loyalty function was essential in the construction of the nation, and it can still be found in many symbolic forms. For example, if we consider the way World Soccer Championship is followed by any citizen in the world, it would be unconceivable that a citizen could support any team belonging to a different nation, even though that team may play better. Of course these students representations receive also the impact of biased textbooks contents, which very often silence a number of violent events, which could be conflicting for the own national representation of the past.

The educational implications of all these conclusions are quite straightforward even though they could be also rather complicated. The first of them is related to help the students to be aware of this relation of moral judgments and historical representations. This is to say to teach the students to work with them. For example, it is clear in the example presented at the beginning of this chapter that the moral implications 
have to do with the real and symbolic actions developed by Georgetown University to not continue silencing this event, as it can be seen in a specific Web site and also to compensate the descendants. But at the same time it is important to contribute to develop a historical representation, which cannot be reduced to a moral understanding. This is related to the possibility of teaching to the students that if there are two sides in a historical conflict there will be also two moral views, and these two moral views could be preventing the possibility of achieving a complex and rigorous historical representation. In the case of slavery, only one side was historically damaged but in other historical events two or more than two sides have been historically damaged. This book is full of cases.

Finally, the six dimensions of national historical narratives, as they are understood by high school and university students deal with the concept of nation itself. This implies the selection of a general scheme, which provides coherence to the way the concept of nation is used in the whole narrative. This feature implies the conceptual view of the nation and its nationals as naturalized political entities, having a kind of "eternal" and "ontological" nature. The concept of nation appears as a key element to develop critical historical thinking in our students. Some of these skills include the development of critical thinking, the understanding of historical time and change and historical causality and source evaluation (Lee 2005; Wineburg et al. 2011). It has been argued in this chapter that learning to think historically entails navigating counterintuitive ideas (Carretero and Lee 2014). For this purpose, I think a serious educational effort is necessary to prepare students for understanding the past and present complexity of the societies in which they live. This would imply a process of conceptual change from misconceptions and lay views on historical concepts in general but on the concept of nation in particular (Carretero et al. 2013). This conceptual change implies to understand that nations are artificial historical concepts invented by nineteenth century, and not natural ones having an ontological and essentialist meaning. In this vein, they are receiving nowadays an intense process of revision. For example, what is the European Union? A nation? A nation of nations? An empire? Definitely it is a political entity trying to define itself in the context of an intense political turmoil whose roots cannot be understood without a complex representation of their historical origins. In this vein, I would like to emphasize that, as present citizens of a world experiencing an intense globalization process, clearly our learning needs to be closer to a flexible and nuanced concept of nation. Migration 
processes will be even more intense in the future, and as this is having an enormous cultural impact, the learning of history in and out of school, particularly when it concerns the nation, has to keep up.

\section{Concluding Thoughts. The Role of Both History Education and Social Psychology in Conflict TRANSFORMATION}

This chapter has tried to present basically the main contributions of several present approaches to the very difficult problem of how to deal with recent and violent past events in both formal and informal educational contexts. With this purpose in mind contributions from social and cultural psychology, history education and cognitive and developmental psychology have been taken into account along with some classical contributions from political science and present historiographical debates. As a concluding part of this chapter, a summary of applied implications will be presented below. Hopefully, they could contribute to serve as cues to apply most of the findings of the majority of the chapters of this book. Thus, these chapters have shown how historical representations in textbooks and other educational devices are full of biased contents, which do not contribute to transform social conflicts. Therefore, the basic question is this: how these representations could be changed? How present social sciences research could provide insights for this purpose? Four main conclusions will be presented.

1. The need of an interdisciplinary approach. To deal both socially and educationally with recent and violent events is a very complex issue. On the one hand, these events are an important part of citizens representations and narratives about the past and very often they do not agree with historiographical research. On the other hand, historiographical research itself is neither an impartial nor completely objective discipline because it could also depend in some cases on social and politically biased influence. In sum, any approach intending to transform social and political conflicts based on the so-called troubled pasts should be very aware that an interdisciplinary account is strongly needed because historical culture and representations are the result of a complex interaction of collective memory, historiography, history education and popular 
culture. From this point of view, it is very hard to predict which one of these influences will be more decisive on transforming citizens historical representations and therefore which one will be also important in order to possibly contribute to reduce conflicts. But anyway taking into account the frequent interaction of several of these influences from an interdisciplinary point of view will always be a positive decision.

2. Is progressive history education enough to transform historical conflicts? Definitely history education research has made enormous progress in the last decades. Initiatives based on historical thinking and historical consciousness approaches have been developing both a theoretical and an applied basis for teaching and learning historical contents in a meaningful way. This is to say with the objective of achieving a constructive and disciplinary understanding and not just a repetitive copy of inert knowledge. But these advances have mainly covered how to teach but not necessarily what to teach. In other words, historical thinking and historical consciousness approaches have focused on the importance of student's cognitive and constructive activities such as how to carry out inquiries and discussions to deal with historical knowledge. But most of the social and political conflicts having historical roots are focused on the content among different versions implying, for example, the answer to very stereotypical and conflictive questions as "who arrived first to this land?" "who started this war?" or "who is the victim in this episode"? Of course in order to generate a process of change of citizens representations on these issues is important to consider the type of cognitive and social activities promoted in and out of the school - this is to say how to teach and learnbut it is also important to consider what is going to be taught and learned. In other words, history education should take into account the importance of silencing and censoring processes. For example, the case of slavery in present societies is a very good example of silencing as described at the beginning of this chapter. Unfortunately, censoring is still present in a number of contemporary societies. Thus, both processes are very common in many educational systems and societies, and definitely they do not contribute to reduce the conflict. Present research and applied attempts to improve history education should take this into account if they intend to contribute to transform conflicts. As it is well known, 
silencing and censoring could reduce them in the short term but their further implications are always negative in the long term.

3. Deconstructing the own nation through reflecting on the conflict.

As mentioned above, political conflicts based on historical representations are very often based on two dimensions. This is to say they have at the same time a national and a recent character. The first feature is not a surprise at all because history education has been traditionally considered an essential piece of most of educational systems since nineteenth century, and even before, to build and maintain national identities. Therefore, it is precisely its national character in interaction with its recency the center of the conundrum to be solved. This is to say any attempt to discuss new information contradicting prior representations, based, for example, on new data obtained by historians, will be facing an intense defensive reaction because citizens national identities will be challenged. But if history education does not go in this direction trying to change stereotypical historical representations there is no way to contribute to conflict reduction and reconciliation. What to do then? This is precisely what previous pages about the teaching of historical narratives have tried to answer. This is to say I have analyzed a six dimensions view of historical narratives emphasizing how each one of them could be approached in such a way that they could help the citizens to contextualize their representations about the past and particularly their view about a monological and essentialist view of past events. As these dimensions have been analyzed before in detail, it is not necessary to consider again their possible contribution to reduce social and political conflicts but I think it is convenient to insist on the dramatic importance of establishment of the historical subject. Usually citizens establish this subject basically through a historical view based on an endurable and almost eternal continuity between themselves and diverse subjects of the past. This is to say when citizens along the world use a "we" as subject of something that happened in the past they represent themselves as the only and genuine descendants of an idealized historical subject which does not exist anymore. In other words, this "we" consists of an incredible mixture of present and past but probably most of the citizens are not really conscious of such a mystification. As stated before, the establishment of this imaginary historical subject is probably the nucleus of the rest of the narratives dimensions 
related to cognitive, emotional and moral issues. Therefore, if history education is able to help citizens to deconstruct this idealized historical subject, it is highly probable that the rest of the narratives dimensions will be also affected and social and political conflicts could be reduced, at least from the point of view of their historical representations which usually provide justifications for not trying to look for more peaceful futures. But how to promote a historical critical thinking which could contribute to that deconstruction? Definitely the development of disciplinary historical view among the citizens would be of great help. This is to say the dissemination of the idea that historical representations are not closed views but dynamic and open interpretations of the past, which could and should be changed according to historical research. In this sense, dialogical activities and open-minded discussions would be of great help because they would contribute to the appearance of a reflective attitude among citizens.

\section{Transforming narratives about the Other}

Above we have outlined and elaborated the importance and impact of historical narratives and representations of the past on conflict resolution processes. More specifically, we have focused on national narratives and how these ought and can be deconstructed in order to facilitate more positive social outcomes. In addition to this, we will briefly outline the importance of narratives people usually have about out-groups and/or former enemy.

Because of both our limited capacity to process information and physical/social complexity and social and political influences, we categorize not only objects but also people into groups. The process of differentiating "us" and "them" is a universal element of intergroup relations. Social psychological research shows that we view "us" (the in-group) as better, superior, more diversified and more moral, while we view "them" (the out-group) as inferior, bad, more homogeneous and less moral. Most the chapters of this book have been based on this classical theoretical distinction. These and similar perceptions are even more pronounced in (post) conflict settings marked by grave human rights violations and constitute a major barrier to successful conflict resolution and sustainable intergroup reconciliation.

Recent research points to the importance of representing out-group members in a more heterogeneous and positive moral manner. More 
specifically, research by Bilewicz and Jaworska (2013; also in this volume) indicates that bringing people together while exposing them to stories of heroic rescuers increased positive affect and perceived similarity between Poles and Jews. The narratives of historical rescuers of Jews during WWII overcame the negative impact of the past on intergroup contact. The authors argued that presenting people with stories of heroic helpers is very important for reconciliation after mass violence as it may prevent entitative categorizations of groups as exclusively victims or perpetrators.

In addition, research that examined the effects of a contact intervention containing narratives of moral exemplars on reconciliation processes in the post-genocide setting of Bosnia and Herzegovina (Čehajić-Clancy and Bilewicz, in press) has found that focusing on moral exemplars increased reconciliatory beliefs due to enhanced forgiveness among both former victims and perpetrators.

Consequently, we suggest that the key to reconciliation is the acknowledgment of historical moral variability by realizing that among out-group members some people were perpetrators, but some of them could be also victims, passive or active bystanders and even heroic helpers (Čehajić-Clancy et al. 2016). Exposing people to such individualized and personalized stories of moral out-group members could influence current relations between historically conflicted groups by inducing trust and fostering contact, resulting in reconciliation.

\section{Notes}

1. http://www.nytimes.com/2016/04/17/us/georgetown-universitysearch-for-slave-descendants.html? (Retrieved May 14, 2017).

2. It should be noted that Pope Gregory 16th condemned the slavery by 1839.

3. http://slavery.georgetown.edu/

4. It is also fascinating to see how much time it took to acknowledge the need to remember the history of North American natives in the USA. The National Museum of the American Indians did not open until 2004!

5. It is very interesting to compare the lack of interest on history as a subject matter that many students show in the schools with the enormous interest historical films, novel and documentary citizens have in many societies. This contrast could be indicating a lack of adequate teaching methods in numerous schools all over Western countries. 
6. The field of history education witnessed a number of intense debates about the developmental capacities of students. These were related to Piaget versus Vygotsky controversies, so frequent in discussing the influences of development and learning processes on students' educational achievements.

7. For recent developments in history education, it is important to consider a number of related programs and European developments (Thünemann et al. 2014).

8. As it is well known at the time of the Civil War (1936-1939) Spain was divided into two sides, the republican and the national. The first was leaded by the legitimate republican government and the second one was leaded by the General Franco who initiated the conflict by an attempt of coup d'état. Recent studies (Preston 2012) showed that in the national side about 160,000 were killed and that in the republican side there was about 30,000. After the war, the Franquist government provided recognition to these people and economic help to their families.

\section{REFERENCES}

Altamira, R. (1891). La enseñanza de la historia. Madrid: Fortanet.

Anderson, B. (1983). Imagined communities: Reflections on the origin and spread of nationalism. (Rev. ed., 1991). London: Verso.

Aries, P., \& Duby, G. (1992). A history of private life, Vol I: From Pagan Rome to Byzantium. Cambridge, MA: Harvard University Press.

Baptist, E. E. (2014). The half has never been told: Slavery and the making of American Capitalism. NY: Basic Books.

Barton, K. C. (2008). Research on students ideas about history. In L. Levstik \& C. A. Thyson (Eds.), Handbook of research on social studies education (pp. 239-258). New York: Routledge.

Barton, K. (2017). Shared principles in history and social science education. In M. Carretero, S. Berger, \& M. Grever (Eds.), Palgrave handbook of research in historical culture and education. Basingstoke: Palgrave.

Barton, K. C., \& Levstik, L. S. (1996). "Back when God was around and everything": Elmentary children's understanding of historical time. American Educational Research Journal, 33(2), 419-454.

Barton, K. C., \& Levstik, L. S. (2004). Teaching history for the common good. Mahwah, NJ: Lawrence Erlbaum Associates.

Beck, I. L. \& Mackeown, M. G. (1994). Outcomes of history instruction: Paste-up accounts. In M. Carretero \& J. F. Voss (Eds.), Cognitive and instructional on history and social sciences (pp. 237-255). Hillsdale, NJ: Erlbaum. 
Bentrovato, D., Korostelina, K. V., \& Schulze, M. (Eds.). (2016). History can bite: History education in divided and postwar societies. Göttingen: V \& $\mathrm{R}$ Unipres

Berger, S. (2012). De-nationalizing history teaching and nationalizing it differently! Some reflections on how to defuse the negative potential of national(ist) history teaching. In M. Carretero, M. Asensio, \& M. RodríguezMoneo (Eds.). (2012). History education and the construction of national identities. Charlotte, NC: Information Age Publishing.

Berger, S. (2014). The past as history: National identity and historical consciousness in modern Europe. Basingstoke: Palgrave.

Berger, S., Lorenz, C., \& Melman, B. (Eds.). (2012). Popularizing national pasts. 1800 to the present. New York: Routledge.

Bilewicz, M., \& Jaworska, M. (2013). Reconciliation through the righteous: The narratives of heroic helpers as a fulfillment of emotional needs in PolishJewish intergroup contact. Journal of Social Issues, 69(1), 162-179.

Boyd, C. P. (1997). Historia Patria: Politics, history and national identity in Spain 1875-1975. Princeton: Princeton University Press.

Braudel, F. (1990). Écrits sur l'histoire II. Paris: Flammarion

Bruner, J. (1966). Toward a theory of instruction. Cambridge, MA: Harvard University Press.

Burke, P. (1990). The French historical revolution: The Annales School, 19291989. Cambridge: Polity Press.

Carretero, M. (2011). Constructing patriotism. Teaching history and memories in global worlds. Charlotte, CT: Information Age Publishing.

Carretero, M. (2017). Teaching history master narratives: Fostering imaginations. In M. Carretero, S. Berger, \& M. Grever (Eds.), Palgrave handbook of research in historical culture and education. Basingstoke: Palgrave

Carretero, M., \& Bermudez, A. (2012). Constructing histories. In J. Valsiner (Ed.), Oxford handbook of culture and psychology (pp. 625-646). Oxford: Oxford University Press.

Carretero, M., \& Lee, P. (2014). Learning historical concepts. In K. Sawyer (Ed.), Handbook of learning sciences. (pp. 587-604). (2nd edn.). Cambridge: Cambridge University.

Carretero, M., \& van Alphen, F. (2014). Do master narratives change among high school students? A characterization of how national history Is represented, cognition \& instruction. Cognition and Instruction, 32(2), 290-312.

Carretero, M., \& van Alphen, F. (2017). History, collective memories or national memories? How the representation of the past is framed by master narratives. In B. Wagoner (Ed.), Oxford handbook of culture and memory. Oxford, UK: Oxford University Press.

Carretero, M., \& Voss, J. F. (Eds.). (1994). Cognitive and instructional processes in history and social sciences. Hillsdale: Erlbaum. 
Carretero, M., Berger, S., \& Grever, M. (Eds.). (2017). Palgrave handbook of research in historical culture and education. Basingstoke: Palgrave.

Carretero, M., Castorina, J. A., \& Levinas, M. L. (2013). Conceptual change and historical narratives about the nation. A theoretical and empirical approach. In S. Vosniadou (Ed.), International handbook of research on conceptual change (pp. 269-287). (2nd edn.). NY: Routledge.

Carretero, M., Jacott, L., \& López-Manjón, A. (2002). Learning history through textbooks: Are Mexican and Spanish students taught the same story? Learning and Instruction, 12, 651-665.

Carretero, M., López-Manjón, A., \& Jacott, L. (1997). Explaining historical events. International Journal of Educational Research, 27(3), 245-253.

Carretero, M., Lopez, C., Gonzalez, M.F., \& Rodríguez-Moneo. (2012). Students historical narratives and concepts about the nation. In M. Carretero, M. Asensio, \& Rodríguez-Moneo (Eds.), History education and the construction of national identities (pp.153-170). Charlotte, NC: IAP.

Čehajić-Clancy, S., Goldenberg, A., Halperin E., \& Gross, J. (2016). Socialpsychological interventions for intergroup reconciliation: An emotion regulation perspective. Psychological Inquiry, 27(2), 73-88.

Cercadillo, L., Chapman, A., \& Lee, P. (2017). Organizing the past: Historical accounts, significance and unknown ontologies. In M. Carretero, S. Berger \& M. Grever (Eds.), Palgrave handbook of research in historical culture and education. Basingstoke: Palgrave.

Chi, M. T. H., Glaser, R., \& Farr, M. (Eds.). (1988). The nature of expertise. Hillsdale, NJ: Lawrence Erlbaum Associates.

Collingwood, R. G. (1946). The idea of history. Oxford, UK: Oxford University Press.

Conrad, S. (2016). What is global history? Princeton, NJ: Princeton University Press.

Dewey, J. (1915). The aim of history in elementary education. In J. Dewey (Ed.), The school and society. Chicago: The University of Chicago Press.

Dickinson, A. K., Lee, P. J., \& Rogers, P. J. (Eds.). (1984). Learning history. London: Heinemann.

Egan, K. (1997). The educated mind. Chicago, IL: The University of Chicago Press.

Epstein, T. (2009). Interpreting national history. Race, identity, and pedagogy in classrooms and communities. New York: Routledge.

Foster, S. (2012). Re-thinking historical textbooks in a globalized world. In M. Carretero, M. Asensio, \& M. Rodríguez-Moneo (Eds.), History education and the construction of national identities (pp. 49-62). Charlotte, CT: Information Age Publishing. 
Freedman, E. B. (2015). "What happened needs to be told": Fostering critical historical reasoning in the classroom. Cognition and Instruction, 33(4), 357398.

Gadamer, H. G. (1999). Myth in the age of science. In H. G. Gadamer, Hermeneutics, religion, and ethics (pp. 91-102). New Haven, CT: Yale University Press.

Grever, M., \& Stuurman, S. (2007). Beyond the canon: History for the twenty-first century. Basingstoke: Palgrave Macmillan.

Haley, A. (1976). Roots: The saga of an American family. NY: Basic Books.

Halldén, O. (2000). On reasoning in history. In J. F. Voss \& M. Carretero (Eds.), Learning and reasoning in history (pp. 272-278). NY: Routledge.

Hein, L. E., \& Selden, M. (2000). Censoring history: Citizenship and memory in Japan, Germany, and the United States. Armonk, NY: M.E. Sharpe.

Herzog, T. (2017). Historical rights to land: How Latin American states made the past normative and what happened to history and historical education as a result. In M. Carretero, S. Berger, \& M. Grever (Eds.), Palgrave handbook of research in historical culture and education (pp. 91-107). Basingstoke: Palgrave.

Hess, D. E. (2004). Controversies about controversial issues in democratic education. Political Science and Politics, 37(2), 257-261.

Hobsbawm, E. (1990). Nations and nationalism since 1780: Programme, myth, reality. Cambridge: Cambridge University Press.

Kansteiner, W. (2017). Film, the past, and a didactic dead end: From teaching history to teaching memory. In M. Carretero, S. Berger, \& M. Grever (Eds.), Palgrave handbook of research in historical culture and education (pp. 169190). Basingstoke: Palgrave.

Lave, J., \& Wenger, E. (1991). Situated learning: Legitimate peripheral participation. Cambridge University Press.

Lee, P. (2005). Putting principles into practice: Understanding history. In P. Lee, How students learn: History in the classroom (pp. 31-77). Washington, DC: The National Academies Press.

Le Goff, J. (1990). Preface. In A. Brossat, S. Combe, J. Potel, \& J. Szurek (Eds.), Àl'Est, la mémoire retrouvée [Found memory in the East]. Paris: Éditions La Découverte.

Limón, M., \& Carretero, M. (1998). Evidence evaluation and reasoning abilities in the domain of history: An empirical study. In J. Voss \& M. Carretero (Eds.), Learning and reasoning in history (pp. 252-271). London: Woburn.

Lopez, C., Carretero, M., \& Rodríguez-Moneo, M. (2015a). Conquest or reconquest? Students' conceptions of nation embedded in a historical narrative. Journal of the Learning Sciences, 24(2), 252-285. 
Lopez, C., Carretero, M., \& Rodríguez-Moneo, M. (2015b). Telling a national narrative that is not your own. Does it enable disciplinary historical consumption? Culture and Psychology, 4, 547-571.

Lorenz, C. (2014). Blurred lines. History, memory and the experience of time. International Journal for History, Culture and Modernity, 1(2), 43-62.

Lorenz, C. (2017). "The Times They Are a-Changin". On time, space and periodization in history. In M. Carretero, S. Berger, \& M. Grever (Eds.), Palgrave handbook of research in historical culture and education (pp. 109131). Basingstoke: Palgrave.

Lowenthal, D. (1985). The past is a foreign country. (Rev. Edn., 2015). Cambridge: CUP.

Maggioni, L., vanSledright, B., \& Alexander, P. A. (2009). Walking on the borders: A measure of epistemic cognition in history. The Journal of Experimental Education, 77, 187-214.

Nokes, J. (2017). Historical reading and writing in secondary school classrooms. In M. Carretero, S. Berger, \& M. Grever (Eds.), Palgrave handbook of research in historical culture and education (pp. 553-571). Basingstoke: Palgrave.

Nussbaum, M. \& Cohen, J. (2002). For love of country? A new democracy forum on the limits of patriotism. Boston, MA: Beacon Press.

Páez, D., Bobowik, M., \& Liu, J. (2017). Social representations concepts of the past and competences in history education. In M. Carretero, S. Berger \& M. Grever (Eds.), Palgrave handbook of research in historical culture and education (pp. 491-510). Basingstoke: Palgrave.

Piaget, J. (1933). Psychologie de l'enfant et enseignement de l'histoire. In Bulletin trimestriel de la Conférence intemationale pour I'enseignement de I'histoire, 2, 8-13.

Piaget, J. (1966). The psychology of the child. New York, NY: Basic Books.

Ravitch, D., \& Finn, C. (1987). What do our 17-year-olds know. New York: Basic Books.

Retz, T. (2015). At the interface: academic history, school history and the philosophy of history. Journal of Curriculum Studies, 48(4), 503-517.

Rose, S. O. (2010). What is gender history? London: Polity.

Sand, S. (2010). The invention of the Jewish people. London: Verso.

Seixas, P. (Ed.). (2004). Theorizing historical consciousness. Toronto, Canada: University of Toronto Press.

Seixas, P. (2015). Translation and its discontents: Key concepts in English and German history education. Journal of Curriculum Studies, 47(6), 427-439.

Seixas, P. (2017). Historical consciousness and historical thinking. In M. Carretero, S. Berger, \& M. Grever (Eds.). Palgrave handbook of research in historical culture and education (pp. 59-72). Basingstoke: Palgrave.

Seixas, P., \& Morton, T. (2013). The big six. Historical thinking concepts. Toronto: Nelson Education LTD. 
Shemilt, D. (1980). History 13-16 evaluation study. Edinburgh: Holmes McDougall.

Smeekes, A. N. (2014). The presence of the past. Historical rooting of national identity and current group dynamics. (Doctoral dissertation, Utrecht University).

Taylor, T., \& Guyver, R. (Eds.). (2012). History wars and the classroom: Global perspectives. Charlotte, NC: Information Age Publishing.

Valls, R. (2007). The Spanish Civil War and the Franco dictatorship: The challenges of representing a conflictive past in secondary schools. In E. Cole (Ed.), Teaching the violent past: History education and reconciliation (pp. 155174). New York: Rowman \& Littlefield.

Van Alphen, F., \& Carretero, M. (2015). The construction of the relation between national past and present in the appropriation of historical master narratives. Integrative Psychological and Behavioral Science, 49(3), 512-530.

Van Boxtel, C., \& van Drie, J. (2017). Engaging students in historical reasoning: The need for dialogic history education. In M. Carretero, S. Berger, \& M. Grever, (Eds.), Palgrave handbook of research in historical culture and education (pp. 573-589). Basingstoke: Palgrave.

VanSledright, B. (2008). Narratives of nation-state, historical knowledge, and school history. Review of Research in Education, 32, 109-146.

VanSledright, B. (2010). The challenge of rethinking history education: On practices, theories, and policy. NY: Routledge.

Vosniadou, S. (Ed.). (2013). International handbook of research on conceptual change (pp. 269-287). NY: Routledge.

Wertsch, J. V. (2002). Voices of collective remembering. Cambridge: Cambridge University Press.

Wertsch, J. V., \& Rozin, M. (2000). The Russian Revolution: Official and unofficial accounts. In J. F. Voss \& M. Carretero, Learning and reasoning in history: International review of history education (pp. 39-60) London: Routledge.

Wertsch, J., \& Rozin, M. (2000). The Russian Revolution: Official and unofficial accounts. In J. F. Voss \& M. Carretero (Eds.), Learning and reasoning in history (pp. 39-60). New York, NY: Routledge.

Wineburg, S. S. (1991). Historical problem solving: A study of the cognitive processes used in the evaluation of documentary and pictorial evidence. Journal of Educational Psychology, 83(1), 73-87.

Wineburg, S. (2001). Historical thinking and other unnatural acts. Philadelphia: Temple University Press.

Wineburg, S., Martin, D., \& Montesano, C. (2011). Reading like a historian. NY: Teachers College. 


\section{Author Biography}

Mario Carretero is a Professor of Cognitive Psychology at Autonoma University of Madrid, Spain, where he was Dean of the Faculty of Psychology, and Researcher at FLACSO, Argentina. He has carried out an extensive research on history education from both cognitive and sociocultural approaches. He has published in Journal of the Learning Sciences and Cognition and Instruction. His recent books are History Education and the Construction of National Identities (2012) (co-ed.) and Constructing Patriotism (funded by the Guggenheim Foundation) (2011). He has been Santander Visiting Scholar at the David Rockefeller Center for Latin American Studies of Harvard University (2009) and Bliss Carnochan Visiting Professor at the Humanities Center of Stanford University (2011). His present research interests have to do with an interdisciplinary attempt to study history education issues as it can be seen in Palgrave Handbook of Research in Historical Culture and Education (2017) (co-edited along with S. Berger and M. Grever).

Open Access This chapter is licensed under the terms of the Creative Commons Attribution 4.0 International License (http://creativecommons.org/licenses/ by $/ 4.0 /$ ), which permits use, sharing, adaptation, distribution and reproduction in any medium or format, as long as you give appropriate credit to the original author(s) and the source, provide a link to the Creative Commons license and indicate if changes were made.

The images or other third party material in this chapter are included in the chapter's Creative Commons license, unless indicated otherwise in a credit line to the material. If material is not included in the chapter's Creative Commons license and your intended use is not permitted by statutory regulation or exceeds the permitted use, you will need to obtain permission directly from the copyright holder.

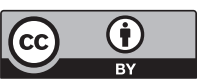

